PHYSICAL REVIEW D 90, 010002 (2014)

\title{
Announcement: Editor Retired from Physical Review D
}

For the first time in almost forty years, the masthead of Physical Review D does not include Dennis Nordstrom's name as Editor on the top line. Dennis has retired.

Dennis joined the staff of Physical Review D as an Assistant Editor in 1971, a year after the journal began publication, and became Editor five years later. In the years since then, Dennis's leadership has been key to the success of the journal and to the maintenance of its standards. The PRD community owes him a debt of gratitude for his contributions to the journal. Happily, Dennis will continue as a Consulting Editor.

Urs Heller has assumed Dennis's responsibilities as Managing Editor.

Gene D. Sprouse

Editor in Chief

American Physical Society
Erick J. Weinberg

Editor

Physical Review D

Published 1 July 2014

DOI: 10.1103/PhysRevD.90.010002

PACS numbers: $01.10 . \mathrm{Cr}$ 